\title{
TINDAK TUTUR PERLOKUSI GURU DALAM PEMBELAJARAN BAHASA INDONESIA KELAS XI SMK NEGERI 1 SAWIT BOYOLALI
}

\author{
Eka Nur Insani dan Atiqa Sabardila \\ Pendidikan Bahasa Indonesia, \\ Universitas Muhammadiyah Surakarta \\ Jl. A. Yani Tromol Pos 1 Pabelan Kartasura, Surakarta (57127) \\ Atiqa.Sabardila@ums.ac.id \\ Insani.hikaru@gmail.com
}

\begin{abstract}
This study reviews the perlocution speech acts of Indonesian language teachers in class XI SMK 1 Sawit, Boyolali. This research aims to describe the classification of perlocution speech acts in Indonesian language teachers in class XI SMK Negeri 1 Sawit, Boyolali and to describe its functions. This research used descriptive qualitative methods. The analyses techniques used in this research refer to free skilled, technical notes, and recording. The results showed that there are four types of perlocution speech acts. They are directive-perlocution speech act, expressive-perlocution speech act, representative-perlocution speech acts and commissive-perlocution speech acts. The directive-perlocution speech acts were found in the forms of orders, reservations and giving advice. The expressive perlocution speech acts involves hatred, pleasure, excitement. The representative form of speech acts include affirmation, description, statement of facts and conclusions. The commissive form of speech acts include denial. The results of this research showed that the perlocution speech acts function found in Indonesian language teachers are the functions for competitiveness and fun.
\end{abstract}

Keywords: perlocussion speech acts, Indonesian language teachers, SMK N 1 Sawit

\begin{abstract}
ABSTRAK
Penelitian ini mengkaji tindak tutur perlokusi guru dalam pembelajaran Bahasa Indonesia Kelas XI SMK Negeri 1 Sawit Boyolali. Penelitian ini bertujuan untuk: (1) mendeskripsikan tindak tutur perlokusi guru dalam pembelaran Bahasa Indonesia kelas XI SMK Negeri 1 Sawit Boyolali, dan (2) fungsi tindak tutur perlokusi guru dalam pembelajaran Bahasa Indonesia kelas XI SMK Negeri 1 Sawit Boyolali. Jenis penelitian ini adalah deskriptif kualitatif. Teknik penelitian yang digunakan berupa teknik simak bebas libat cakap, teknik catat, dan teknik rekam. Dari temuan ditunjukkan ada empat jenis tindak tutur perlokusi, yaitu tindak tutur perlokusi direktif, perlokusi ekspresif, perlokusi representatif, dan perlokusi komisif. Dalam tindak tutur perlokusi direktif berupa perintah, pemesanan, dan pemberian saran. Tindak tutur perlokusi ekspresif berupa kebencian, kesenangan, dan kegembiraan. Tindak tutur perlokusi representatif berupa penegasan, pendeskripsian, pernyataan suatu fakta, dan simpulan. Tindak tutur komisif berupa penolakan. Hasil analisis menunjukkan fungsi tindak tutur perlokusi yang ditemukan pada guru dalam pembelajaran bahasa Indonesia yaitu fungsi kompetitif dan fungsi menyenangkan.
\end{abstract}

Kata Kunci: perlokusi, tuturan guru bahasa Indonesia 


\section{PENDAHULUAN}

Manusia menggunakan bahasa untuk memberi dan menerima informasi melalui berbagai media yang bersifat langsung maupun tidak langsung yang berbentuk audio maupun visual. Maksud dan tujuan berkomunikasi di dalam peristiwa tutur diwujudkan dalam sebuah kalimat. Kalimat yang diucapkan oleh seorang penutur dapat diketahui apa yang diinginkan pembicara/ penutur sehingga dapat dipahami oleh mitra tutur.

Tindakan-tindakan bertutur dimaksudkan dengan bahasa yang komunikatif agar yang disampaikan oleh penutur (O1) dapat diterima oleh pendengar (O2). Kegiatan bertutur antara penutur dan pendengar dibantu oleh keadaan sekitar lingkungan tuturan itu. Keadaan semacam ini termasuk juga tuturan-tuturan yang lain disebut peristiwa tutur (Yule, 2006:82).

Peristiwa tutur antara $(\mathrm{O} 1)$ dengan $(\mathrm{O} 2)$ terjadi pada saat proses belajar- mengajar berlangsung, yakni dalam pelajaran Bahasa Indonesia di kelas XI. Tuturan yang diucapkan oleh kedua guru Bahasa Indonesia kelas XI ini tidak jauh berbeda diantara keduanya. Tindak tutur perlokusi adalah sebuah tuturan yang diutarakan oleh seseorang sering kali mempunyai daya pengaruh (perlocutionary force) atau efek bagi yang mendengarnya (Wijana dan Rohmadi, 2009:24). Berdasarkan pengertian tersebut tuturan yang diucapkan oleh kedua guru Bahasa Indonesia muncul tindak perlokusi yang cukup banyak. Selama proses pembelajaran berlangsung hampir semua tuturan yang diucapkan oleh guru mengandung banyak tindak perlolusi.

Dalam pembelajaran tersebut tindak perlokusi atau tindak tutur direktif dominan muncul. Tindak tutur direktif ini merupakan bagian dari klasifikasi tindak perlokusi. Setiap kali guru memberikan penjelasan kepada siswanya selalu muncul tindak perlokusi atau guru tersebut selalu bertutur dan memberikan efek kepada siswanya untuk melakukan apa yang dikatakan oleh guru tersebut. Tuturan tersebut mengandung perintah, pemesanan, permohonan, dan pemberian saran. Tuturan tersebut kurang lebih mengandung keempat macam hal itu. Namun, dalam tindak tutur perlokusi terdapat jenis tindak tutur yang lain, diantaranya komisif, ekspresif, dan representatif. Jenis-jenis tindak tutur tersebut mempunyai maksud atau arti yang disampaikan oleh guru kepada siswanya.

Berdasarkan latar belakang penelitian ini ingin dikaji tentang bagaimana tindak perlokusi diperoleh. Guru Bahasa Indonesia kelas XI melakukan tuturan di dalam kelas pada saat proses pembelajaran berlangsung. Dari tuturan guru pada saat pembelajaran Bahasa Indonesia diperoleh tindak tutur perlokusi dan jenisnya. Alasan inilah yang mendasari dilakukan penelitian terhadap tindak perlokusi guru. Komunikasi yang dilaksanakan pada situasi tertentu yakni di dalam sekelompok Siswa Kelas XI SMK Negeri 1 Sawit Boyolali. Ini mendasari penulis memilih pragmatik sebagai tinjauan dalam penelitian ini. Oleh karena itu, penelitian ini diberi judul "Tindak Perlokusi Guru dalam Pembelajaran Bahasa Indonesia Kelas XI SMK Negeri 1 Sawit Boyolali."

Perumusan masalah pada penelitian ini adalah sebagai berikut. (1) Bagaimana klasifikasi tindak tutur perlokusi guru dalam pembelajaran bahasa Indonesia kelas XI SMK Negeri 1 Sawit Boyolali? (2) Bagaimana fungsi tindak tutur perlokusi guru dalam pembelajaran bahasa Indonesia kelas XI SMK Negeri 1 Sawit Boyolali? Tujuan penelitian ini mendeskripsikan klasifikasi tindak tutur perlokusi guru dalam pembelajaran bahasa Indonesia kelas XI SMK Negeri 1 Sawit Boyolali serta mengkaji fungsi tindak tutur perlokusi guru dalam pembelajaran bahasa Indonesia kelas XI SMK Negeri 1 Sawit Boyolali. Penelitian ini diharapkan dapat memberikan manfaat teoretis dan manfaat praktis. Manfaat teoretis diharapkan penelitian dapat memberikan pengetahuan tentang ilmu linguistik khususnya pada bidang pragmatik. Adapun manfaat praktis diharapkan dapat memberikan informasi khusunya bagi pembaca sehubungan dengan tindak tutur perlokusi, selain itu bermanfaat bagi peneliti, yakni dapat 
memberikan ilmu pengetahuan dan pengembangan sehubungan dengan penelitian ini. Manfaat bagi pendidik, khususnya guru bahasa Indonesia, adalah dapat menambah pengetahuan dan pemahaman mengenai tindak tutur dalam bidang pragmatik.

Pragmatik merupakan cabang ilmu bahasa yang semakin dikenal pada masa sekarang ini walaupun kira-kira dua dasa warsa silam ilmu ini jarang atau hampir tidak pernah disebut oleh para ahli bahasa. Hal ini dilandasi oleh semakin sadarnya para linguis bahwa upaya menguak hakikat bahasa tidak akan membawa hasil yang diharapkan tanpa disadari pemahaman terhadap pragmatik, yakni bagaimana bahasa itu dalam komunikasi (Leech dalam Wijana, 2009: 6).

Tarigan (1986) menjelaskan pengertian pragmatik adalah menelaah ujaran-ujaran khusus dalam situasi khusus dan tertutama sekali memusatkan perhatian dan beragam cara yang merupakan wadah aneka konteks performansi bahasa. Pragmatik menelaah pengaruh fenomena supramansi ujaran, dialek, dan register dan memandang performansi ujaran pertama sebagai suatu kegiatan sosial ditata oleh aneka ragam sosial.

Menurut Tarigan (1987) tindak tutur dibagi menjadi tiga, yaitu pertama tindak lokusi adalah melakukan tindakan untuk menyatakan sesuatu. Kedua, tindak ilokusi adalah melakukan suatu tindakan dalam mengatakan sesuatu. Ketiga, tindak perlokusi adalah melakukan sesuatu tindakan dengan menyatakan sesuatu. Berdasarkan pengertian, maka tindak tutur itu saling berkaitan antar satu dengan yang lain. Menurut Searle (dalam Wijana dan Rohmadi, 2009:21) tindak perlokusi adalah sebuah tuturan yang diutarakan oleh seseorang sering kali mempunyai daya pengaruh (perlocutionary force) atau efek bagi yang mendengarnya. Tindak ini disebut The Act of Affecting Somerthing.

Menurut Yule (2006:92) sistem klasifikasi terbagi manjadi beberapa kelompok diantaranya: (1) Deklarasi, yaitu jenis tindak tutur yang mengubah dunia melalui tuturan. Berikutnya adalah (2) Representatif, yaitu jenis tindak tutur yang menyatakan apa yang diyakini penutur kasus atau bukan. Berikutnya lagi adalah (3) Ekspresif, yaitu jenis tindak tutur yang menyatakan sesuatu yang dirasakan penutur. Tindak tutur itu mencerminkan pernyataan-pernyataan psikologis dan dapat berupa pernyatan kegembiraan, kesulitan, kesukaan, kebencian, kesenangan, dan kesengsaraan. Selanjutnya, tindak tutur (4) Direktif, jenis tindak tutur yang dipakai oleh penutur untuk menyuruh orang lain melakukan sesuatu. Jenis tindak tutur ini menyatakan apa yang menjadi keinginan penutur. Tindak tutur ini meliputi: perintah, pemesanan, pemohonan, dan pemberian saran. Terakhir, tindak tutur (5) Komisif, yaitu jenis tindak tutur yang dipahami oleh penutur untuk mengikatkan dirinya terhadap tindakan-tindakan di masa yang akan datang. Tindak tutur ini menyatakan apa saja yang dimaksud oleh penutur. Tindak tutur ini dapat berupa: janji, ancaman, dan penolakan ikrar.

\section{METODE PENELITIAN}

Jenis penelitian ini adalah deskriptif kualitatif. Sumber data penelitian ini adalah transkripsi tuturan guru Bahasa Indonesia kelas XI SMK Negeri Sawit Boyolali. Data dalam penelitian ini berupa ungkapan tindak tutur dalam upaya mencari tindak tutur perlokusi guru dalam pembelajaran Bahasa Indonesia.

Teknik pengumpulan data menggunakan teknik simak. Teknik ini memiliki teknik dasar yang berwujud teknik sadap. Teknik sadap disebut sebagai teknik dasar simak karena pada hakikatnya penyimakan diwujudkan dengan penyadapan (Mahsun, 2005:90). Teknik sadap memiliki teknik lanjutan, yakni teknik simak bebas libat cakap. Selanjutnya, dilakukan perekaman dan pencatatan. Teknik ini digunakan untuk memperoleh tindak tutur perlokusi guru dalam pembelajaran bahasa Indonesia.

Metode analisis data yang digunakan berupa metode padan ekstralingual, yaitu menghubungkan masalah bahasa dengan hal yang berada di luar bahasa. Penelitian ini 
menggunakan metode padan bagian sub jenis kelima, yaitu dengan alat penentu mitra wicara atau mitra tutur (Sudaryanto, 2015:18). Teknik yang digunakan berupa teknik dasar, yakni "teknik pilah unsur penentu atau teknik PUP. Adapun alatnya ialah daya pilah yang bersifat mental yang dimiliki oleh peneliti. Alat penentu dari daya pilah ini yang dimaksud ialah tuturan yang diucapkan oleh guru pada saat pembelajaran. Berdasarkan tuturan-tuturan yang diperoleh dapat dipilah sesuai dengan jenis dan klsifikasinya (Sudaryanto. 2015:21).

Metode padan ekstralingual digunakan, khususnya bagian sub jenis kelima, yaitu dengan alat penentu mitra wicara atau mitra tutur. Teknik yang digunakan yaitu teknik dasar pilah unsur penentu. Pada teknik dasar ini dengan menggunakan daya pilah sebagai pembeda reaksi dan kadar keterdengaran. Adapun maksud dari pernyataan ini, dalam kaitannya dengan mitra wicara, dapat dibedakan adanya reaksi yang bermacam-macam dari kadar keterdengarannya. Daya pilah yang digunakan peneliti ini berdasarkan tuturan-tuturan yang disampaikan, dan mengandung kadar keterdengaran, misalnya satuan lingual yang mencakup: kalimat perintah, kalimat tanya, kalimat berita, dll. (Sudaryanto, 2015:25)

Keabsahan data dalam penelitian ini dilakukan dengan metode trianggulasi. Trianggulasi (Moelong, 2014:330) adalah teknik pemeriksaan keabsahan data sesuatu di luar data untuk pengecekan atau sebagai pembanding terhadap data itu. Denzin (dalam Moleong, 2014: 330) membedakan empat macam trianggulasi sebagai teknik pemeriksaan yang memanfaatkan sumber, metode, penyidik, dan teori.

Berdasarkan empat macam trianggulasi tersebut, dipiilih trianggulasi teori. Bahwa data tersebut tidak dapat diperiksa derajat kepercayaan dengan satu atau lebih teori. Pemilihan trianggulasi teori keabsahan data diperoleh dengan menganalisis data berdasarkan teori yang telah dipilih atau yang lebih tepat untuk menghasilkan data yang valid.

\section{HASIL PENELITIAN DAN PEMBAHASAN}

Berdasarkan pemilihan data, diperoleh 63 data yang akan dianalisis. Data tersebut diklasifikasi berdasarkan tindak tutur perlokusi. Adapun data yang diambil bersumber dari tiga rekaman yanga telah dilakukan oleh peneliti, yakni: (1) rekaman pertama, di kelas XI TKJ 3, (2) rekaman kedua, di kelas X1 TKJ 1, dan (3) rekaman ketiga, di kelas XI Farmasi 1.

Data yang dianalisis difokuskan pada tuturan guru bahasa Indonesia yang mengandung tindak tutur. Tuturan yang digunakan guru bahasa Indonesia bervariasi sehingga tuturan tersebut dapat diterima oleh pendengar. Tuturan ini terjadi pada saat proses belajar-mengajar di dalam kelas XI. Tuturan guru bahasa Indonesia akan dianalisis berdasarkan teori pragmatik. Data-data tersebut diklasfikasi sesuai dengan teori yang digunakan.

\section{Tindak Tutur Perlokusi Guru dalam Pembelaran Bahasa Indonesia Kelas XI SMK Negeri 1 Sawit Boyolali.}

Dengan merujuk pada jenis tindak tutur yang dingkapkan oleh Yule (2006), dalam penelitian ini, disajikan analisis bentuk tindak tutur yang terbagi menjadi beberapa klasifikasi tindak tutur diantaranya: (1) tindak tutur direktif, (2) tindak tutur ekspresif, (3) tindak tutur representatif, dan (4) tindak tutur komisif. Berikut diantaranya.

\section{a. Tindak tutur Direktif}

Tindak tutur direktif ialah jenis tindak tutur yang dipakai oleh penutur untuk menyuruh orang lain untuk melakukan sesuatu. Jenis tindak tutur ini menyatakan apa yang menjadi keinginan penutur. Dalam tahapan klasifikasi data tindak tutur direktif terdapat klasifikasi data lanjutan, yaitu tindak tutur direktif meliputi; perintah, pemesanan, permohonan, dan pemberian saran. Pada penelitian ini ditemukan 32 data tindak tutur perlokusi direktif. 
Tindak tutur perintah merupakan kategori dari tindak tutur direktif. Tindak tutur perintah ini terdapat 29 data.

"(1) Suf jadi satu aja Suf, sini suf. Ayo yang lainnya wes . Buku bahasa Indonesia ne 'buku bahasa Indonesianya silakan dikeluarkan! (sumber: R1)"

Contoh (1) pada O1 (penutur) yaitu seorang guru bahasa Indonesia. Tuturan tersebut mengandung tuturan direktif yang berarti menyuruh untuk melakukan sesuatu. Indeksalnya tuturan tersebut meminta siswanya untuk mengeluarkan buku bahasa Indonesianya dan akan segera dibahas bersama-sama. Tuturan (1) merupakan ke dalam klasifikasi lanjutan yang yaitu tindak tutur 'perintah'. Contoh (1) merupakan perintah yang menunjukkan 'siswa diminta untuk mengeluarkan buku bahasa Indonesia'.

\section{b. Tindak Tutur Ekspresif}

Tindak tutur ekpresif adalah jenis tindak tutur yang menyatakan sesuatu yang dirasakan oleh penutur. Tindak tutur ini mencerminkan penyataan-pernyataan psikologis dan dapat berupa pernyataan kegembiraan, kesulitan, kesukaan, kebencian, kesenengan, atau kesengsaraan. Dalam tahapan klasifikasi data tindak tutur ekpresif terdapat klasifikasi lanjutan, yaitu: kesenangan, kebencian, dan kegembiraan. Data yang dikumpulkan pada jenis ini terdapat 20 data.

\section{"(2) Seng crito berarti wes selesai (R2)"}

Contoh (2) merupakan tindak ekspresif. Tindak tutur ekspresif yaitu tindak tutur yang menyatakan sesuatu yang dirasakan oleh penutur. Dalam tuturan itu penutur mengucapkan kalimat "Seng crito berarti wes selesai?", dengan rasa benci. Rasa benci dalam konteks tuturan ini dalam artian penutur merasakan kekesalan terhadap siswanya. Pada contoh (2) merupakan klasifikasi tindak tutur ekspresif yaitu 'kebencian', makksudnya penutur dalam tuturan itu menyampaikannya dengan rasa kesal.

\section{c. Tindak Tutur Representatif}

Representatif adalah jenis tindak tutur yang menyebabkan apa yang diyakini penutur kasus atau bukan. Dalam tahapan klasifikasi tindak tutur representatif terdapat klasifikasi lanjutan, yaitu pernyataan suatu fakta, penegasan, pendeskripsian, dan simpulan. Contoh yang terkumpul sebanyak 8 data.

“(3) Kalo kalian membuat parafrase jadi kalian harus membaca keseluruhan teks (R1)"

Contoh (3) termasuk tindak tutur representatif yang berarti menyatakan suatu kasus atau bukan. Contoh tersebut menjelaskan bahwa kalimat itu merupakan tindak representatif. Suatu kasus bahwa kalimat itu suatu pernyataan yang belum diketahui oleh mitra tutur (siswa). Pada contoh (3) penutur berusaha menyampaikan pesan kepada mitra tutur dengan jelas. Contoh (3) tersebut merupakan klasifikasi lanjutan dari tindak tutur ekspresif yaitu menyatakan penegasan. 


\section{d. Tindak Tutur Komisif}

Dalam tahapan klasifikasi data tindak tutur komisif terdapat klasifikasi lanjutan, yaitu penolakan. Komisif ialah jenis tindak tutur yang dipahami oleh penutur untuk mengikat dirinya terhadap tindakan di masa yang akan datang. Tindak tutur ini menyatakan apa saja yang dimaksudkan oleh penutur. Jenis tindak tutur ini terdapat 3 data.

"(4) Lho kan, neng gah aku yen nyanyine gur padamu negeri. Sekali-kali nyanyine Jowo lhah, ehh daerah (R2)"

Contoh (4) merupakan tindak tutur komisif yang masuk dalam kategori tuturan penolakan. Kutipan pada tuturan tersebut menyebutkan adanya penolakan yang dilakukan oleh penutur yang dapat dilihat pada kutipan "neng gah aku yen nyanyine gur padamu negeri”.

\section{Fungsi Tindak Tutur Perlokusi Guru Bahasa Indonesia Kelas XI SMK N 1 Sawit Boyolali}

Searle (1993:162) mengemukakan fungsi tindak tutur yaitu situasi yang berbeda-beda menurut adanya jenis-jenis dan derajat sopan santun yang berbeda juga. Fungsi-fungsi dapat diklasifikasikan menjadi empat jenis, yakni: kompetitif (competitive), menyenangkan (Convivial), bekerja sama (collaborative), dan bertentangan (conflictive). Dalam penelitian ini terdapat dua jenis fungsi tindak tutur perlokusi. Fungsi-fungsi tersebut dapat diuraikan sebagai berikut.

\section{a. Kompetitif (competitive)}

Fungsi kompetitif adalah tuturan yang tidak bertata krama atau kurang santun. Tujuan perlokusi ini sejalan dengan tujuan sosial. Pada fungsi ini tujuan sosial kurangnya sopan santun. Dalam penelitian ini terdapat fungsi kompetitif. Contoh berikut ini berupa tuturan yang mengandung tindak tutur direktif, seperti: memerintah, dan meminta.

“(1) Esdi lungguhe dijadikan satu aja duduknya. (sumber: R1)”

Contoh (1) merupakan fungsi kompetitif. Dalam tuturan di atas penutur memerintahkan mitra tutur/siswanya untuk duduk menjadi satu di barisan depan. Tujuaan perlokusi di atas sejalan bersama tujuan sosial, yakni memerintah. Pada fungsi ini bentuk sopan santun menjadi berkurang. Pada tuturan ini fungsi kompetitif yang muncul yakni penutur memerintah kepada mitra tutur.

\section{b. Menyenangkan (Concivial)}

Fungsi menyenangkan adalah tuturan yang sopan. Tujuan perlokusi sejalan dengan tujuan sosial. Tujuan sosial ini merupakan sifat yang positif karena bersifat lebih sopan dan menyenangkan. Dalam penelitian ini terdapat fungsi menyenangkan. Data yang termasuk dalam fungsi ini yaitu tindak tutur ekspresif, salah satunya mengucapkan selamat. Berikut ini contohnya.

“(2) Ini kelas yang paling bagus. (sumber: R3)" 
Contoh (2) Tuturan tersebut merupakan fungsi menyenangkan. Mitra tutur akan senang jika mendapat pujian. Tujuan perlokusi ini sejalan dengan tujuan sosial. Penutur dalam kutipan diatas mengucapkan selamat atau pujian kepda mitra tutur. Pujian tersebut yaitu bahwa kelas ini merupakan kelas yang paling bagus karena siswanya rata-rata tidak ada yang bolos. Dalam hal ini mitra tutur merasa senang dengan pujian yang diberikan oleh penutur.

Berdasarkan data sejumlah 64 tuturan perlokusi yang berasal dari tuturan guru bahasa Indonesia ketika pembelajaran berlangsung, sudah diklasfikasikan sesuai dengan jenis-jenis tindak tutur perlokusi, diantaranya: (1) tindak tutur direktif, (2) tindak tutur representatif, (3) tindak tutur ekspresif, dan (4) tindak tutur komisif. Dalam penelitian tersebut tidak hanya disajikan klasifikasi tindak tutur, akan tetapi disajikan pula fungsi tindak tutur. Berdasarkan data yang telah dirinci, fungsi tindak tutur perloksusi terdiri dari dua fungsi, yaitu fungsi kompetitif dan fungsi menyenangkan.Fungsi kompetitif terdapat 32 data tuturan, sedangkan fungsi menyenangkan terdapat 1 data tuturan.

Jika dikaitkan dengan penelitian Dewi Nafianti (2012), tulisan ini memiliki persamaan dengan yang dia lakukan. Keduanya sama-sama meneliti tindak tutur perlokusi yang menghasilkan tuturan serta analisis tuturannya. Perbedaannya, pada penelitian yang peneliti lakukan menggunakan objek tindak tutur perlokusi yang diperoleh dari guru Dari tuturan tersebut dihasilkan beberapa klasifikasi, diantaranya: (1) tindak tutur direktif (: perintah, pemesanan, dan pemberian saran), (2) representatif (: kesenangan, kebencian, dan kegembiraan), (3) ekspresif (: pernyataan suatu fakta, penugasan, pendeskripsian, dan simpulan) dan (4) komisif (penolakan). Selanjutnya, fungsi tindak tutur yaitu kompetitif dan menyenangkan. Adapun penelitian yang dilakukan oleh Dewi (2012) adalah tindak tutur perlokusi dakwah ustad Maulana. Hasil penelitian tersebut dapat ditemukan empat jenis tindak tutur perlokusi, yaitu tindak tutur asertif, tindak tutur direktif, tindak tutur ekspresif, dan tindak tutur deklaratif. Tindak tutur asertif berupa menyakan, memberitahu, mengaskan, dan menjelaskan. Dalam tuturan Dakwah Ustad Maulana terdapat enam jenis tindak perlokusi direktif yang meliputi mengharuskan, melarang, memerintah, menyarakan, menyumpah, dan mengingatkan. Tindak tutur perlokusi ekspresif merupakan tindak tutur yang dimaksudkan penuturnya agar ujarannya diartikan sebagai evaluasi tentang hal yang disebutkan di dalam tuturan itu. Dalam tindak tutur perlokusi ekspresif dalam penelitian ini berupa tuturan meminta maaf, memuji, bersykur, dan menyindir. Tindak perlokusi deklaratif merupakan tindak tutur yang mengungkapkan adanya kesesuaian antara proposisi dengan realitas. Tindak perlokusi direktif yang ditemukan ini hanya berupa tindak tutur mengizinkan. Hasil analisis data dalam penelitian ini menunjukkan fungsi tindak tutur perlokusi yang ditemukan dalam tuturan Dakwah ustad Maulana adalah fungsi kompetitif, menyenangkan, dan bekerja sama.

Begitu pula dengan penelitian Sutrisno (2015). Penelitian ini memiliki persamaan dengan yang dilakukan oleh peneliti. Kedua penelitian ini sama-sama meneliti tindak tutur perlokusi yang menghasilkan tuturan serta analisis tuturannya. Perbedaannya, pada penelitian yang peneliti lakukan menggunakan objek tindak tutur perlokusi yang diperoleh dari guru. Dari tuturan tersebut dihasilkan beberapa klasifikasi, diantaranya (1) tindak tutur direktif (perintah, pemesanan, dan pemberian saran), (2) representatif(kesenangan, kebencian, dan kegembiraan), (3) ekspresif (pernyataan suatu fakta, penugasan, pendeskripsian, dan simpulan), dan (4) komisif (penolakan). Selanjutnya, fungsi tindak tutur yaitu kompetitif dan menyenangkan. Adapun penelitian yang dilakukan oleh Sutrisno (2015) adalah analisis tindak tutur pedagang dan pembeli di pasar Pemangkat Kabupaten Sambas. Hasil penelitian yang telah dilakukan adalah (1) Tindak tutur yang ditemukan dalam komunikasi antara penjual dan pembeli di pasar Pemangkat Kabupaten Sambas, yaitu tindak tutur lokusi, tindak tutur ilokusi, dan tindak tutur 
perlokusi, (2) Jenis tindak tutur lokusi yaitu, lokusi pernyataan, lokusi perintah, dan lokusi pertanyaan, dan (3) Jenis tindak tutur ilokusi asertif, direktif, komisif, dan ekspresif.

Keseluruhan analisis data pada tuturan dalam penelitian ini, secara sistematis dapat dilihat pada dua tabel berikut.

Tabel 1

Klasifikasi Tindak Tutur Perlokusi

\begin{tabular}{cllc}
\hline No & Jenis tindak tutur perlokusi & Jumlah \\
\hline 1. & Direktif & a. perintah & 29 \\
& & b. pemesanan & 2 \\
& & c. pemberian saran & 1 \\
2. & \multirow{2}{*}{ Ekspresif } & a. kebencian & 17 \\
& & b. kesenangan & 2 \\
& & c. kegembiraan & 1 \\
3. & Representatif & a. penugasan & 4 \\
& & b. pendeskripsian & 2 \\
& & c. pernyataan suatu fakta & 1 \\
& & d. simpulan & 1 \\
4. & Komisif & a. penolakan & 3 \\
\hline
\end{tabular}

Tabel 1 di atas menunjukkan bahwa hasil penelitian ini didominasi jenis tindak tutur perlokusi direktif kategori "perintah" dengan jumlah data 29. Jenis tindak tutur pelokusi berikutnya yaitu tindak tutur ekspresif kategori "kebencian" dengan jumlah data 17. Jenis tindak tutur yang lain seperti representatif dan komisif tidak terdapat data yang begitu dominan. Makna yang terkandung dalam tuturan guru bahasa Indonesia yang terdiri dari beberapa macam tindak tutur tersebut memiliki maksud bahwa guru berusaha menyampaikan pesan kepada mitra tutur dengan bentuk tuturan yang berbeda-beda. Keberagaman bentuk tuturan itu bertujuan agar mitra tutur (siswa) dapat memahami tuturan tersebut dengan baik sehingga dapat menberikan informasi kembali kepada penutur.

Tabel 2

Fungsi Tindak Tutur Pelokusi

\begin{tabular}{|c|c|c|}
\hline No & Fungsi Tindak Tutur Perlokusi & Jumlah \\
\hline 1. & Kompetitif & 32 \\
\hline 2. & Menyenangkan & 1 \\
\hline & Jumlah & 33 \\
\hline
\end{tabular}

Fungsi perlokusi kompetitif dalam penelitian ini adalah data yang mengandung tindak tutur direktif. fungsi perlokusi yang kedua, fungsi menyenangkan yaitu data yang mengandung tindak tutur ekspresif. Makna yang terkandung dalam tuturan guru bahasa Indonesia yang mengandung fungsi perlokusi sejalan dengan tujuan sosial. Pada fungsi kompetitif tujuan sosial kurang santun, namun pada fungsi menyenangkan tujuan sosial tersebut bersifat positif karena lebih santun dan menyenangkan.

\section{SIMPULAN}

Berdasarkan perumusan dan pembahasan masalah yang telah disajikan pada bab sebelumnya, maka dapat diperoleh beberapa simpulan. Pertama, tuturan guru bahasa Indonesia memiliki empat jenis tindak tutur yang mengandung tuturan perlokusi yang dijabarkan 
sebagai berikut. (1) Tindak tutur direktif ditemukan dalam 32 data. Perolehan data tersebut diklasifikasikan ke dalam kategori lanjutan. Tindak tutur direktif 'perintah' 29 data, tindak tutur direktif 'pemesanan' 2 data, dan tindak tutur direktif 'pemberian saran' 1 data. (2) Tindak tutur ekspresif terdapat dalam 20 data. Pemerolehan data tersebut memiliki kategori lanjutan diantaranya tindak tutur ekspresif 'kebencian' 17 data, tindak tutur ekspresif 'kesenangan' 2 data, dan tindak tutur ekspresif 'kegembiraan' 1 data. (3) Tindak tutur representatif terdapat dalam 8 data. Pemerolehan data tersebut memiliki kategori lanjutan diantaranya tindak tutur representatif 'penegasan' 4 data, tindak tutur representatif 'pendeskripsian' 2 data, tindak tutur repesentatif 'pernyataan suatu fakta' 1 data, dan tindak tutur representatif 'simpulan' 1 data. (4) Tindak tutur representatif terdapat dalam 8 data. Pemerolehan data tersebut memiliki kategori lanjutan diantaranya tindak tutur representatif 'penegasan' 4 data, tindak tutur representatif 'pendeskripsian' 2 data, tindak tutur repesentatif 'pernyataan suatu fakta' 1 data, dan tindak tutur representatif 'simpulan' 1 data. (5) Tindak tutur komisif terdapat dalam 3 data. Pemerolehan data tersebut memiliki kategori lanjutan, yaitu tindak tutur komisif 'penolakan' sejumlah 3 data.

Pada rumusan kedua dalam tuturan guru bahasa Indonesia terdapat fungsi perlokusi yang terdiri dari dua fungsi. Fungsi pertama adalah fungsi kompetitif yang terdapat dalam 31 data dan fungsi menyenangkan yang terdapat dalam 1 data. Berdasarkan kedua rumusan yang telah dibahas, dapat disimpulkan bahwa makna yang terkandung dalam tuturan guru bahasa Indonesia yang terdiri dari beberapa macam tindak tutur tersebut, memiliki maksud bahwa guru berusaha menyampaikan pesan kepada mitra tutur dengan bentuk tuturan yang berbedabeda. Keberagaman bentuk tuturan itu bertujuan agar mitra tutur (siswa) dapat memahami tuturan tersebut dengan baik sehingga dapat menberikan informasi kembali kepada penutur. Selanjutnya, makna yang terkandung dalam tuturan guru bahasa Indonesia yang mengandung fungsi perlokusi sejalan dengan tujuan sosial. Pada fungsi kompetitif tujuan sosialnya kurang santun, tetapi pada fungsi menyenangkan tujuan sosial tersebut bersifat positif karena lebih santun dan menyenangkan.

\section{DAFTAR PUSTAKA}

Mahsun. 2012. Metode Penelitian Bahasa: Tahapan Strategi, Metode, dan Tekniknya. Jakarta: PT Grefindo Persada.

Moleong, Lexy J. 2014. Metodologi Penelitian Kualitatif. Bandung: PT Remaja Rosdakarya.

Nafianti, Dewi. 2012. “Tindak Tutur Perlokusi dalam Dakwah Ustad Maulana pada Acara "Islam itu Indah" di Trans TV". Skripsi. Surakarta: Universitas Muhammadiyah Surakarta. Diakses pada Sabtu, 21 November 2015.

Sudaryanto. 2015. Metode dan Aneka Teknik Analisi Bahasa: Pengantar Peneltian Wahana Kebudayaan secara Linguistis. Yogyakarta: Universitas Sanata Dharma Anggota APPTI.

Sutrisno, dkk (2015). "Analisis Tindak Tutur Pedagang dan Pembeli di Pasar Pemangkat Kabupaten Sambas”. Jurnal Pendidikan dan Pengajaran I. Volume 4 No 1.

Tarigan, Henry Guntur. 1986. Pengajaran Pragmatik. Bandung: Angkasa.

Wijana, I dewa Putu dan Muhammad Rohmadi. 2009. Analisis Wacana Pragmatik: Kajian Teori dan Analisis. Surakarta: Yuma Pustaka.

Yule, George. 2006. Pragmatik. Yogyakarta: Pustaka Pelajar. 